\title{
Blended Learning and the European Higher Education Area: The Use of WebQuests ${ }^{1}$
}

\author{
Sonia BAELO \\ University of Zaragoza
}

Recibido: 4 April 2009 / Aceptado: 29 September 2009

ISSN: 1697-7467

\begin{abstract}
This paper deals with the new pedagogical approaches that the European Higher Education Area (EHEA) demands in the university system and proposes blended learning as an effective means to meet these demands. Blended learning refers to language courses that combine the use of technology and distant learning with face-toface classes. WebQuests, which are inquiry-oriented activities that elicit higher-order thinking, can be easily combined with face-to-face classroom activities. This blended learning methodology can be an adequate means to adapt language subjects to the EHEA demands. Blended learning and WebQuests elicit higher order thinking, foster the development of instrumental systemic and interpersonal competences and can be easily integrated in an accumulation and transfer system based on ECTS credits.
\end{abstract}

Key words: European Higher Education Area (EHEA), blended learning, WebQuests, English for Specific Purposes (ESP)

Formación combinada y el espacio europeo de educación superior: el uso de WebQuests

RESUMEN: Este artículo gira en torno a las nuevas aproximaciones pedagógicas que el Espacio Europeo de Educación Superior (EEES) demanda en el sistema universitario y propone la formación combinada o blended learning como un modo efectivo de cumplir estas demandas. La formación combinada se refiere a los cursos de idiomas que combinan el uso de nuevas tecnologías y el aprendizaje a distancia con clases presenciales. Las WebQuests, que son actividades de indagación/investigación que suscitan pensamiento de orden superior, pueden ser fácilmente combinadas con actividades en clases presenciales. Esta metodología puede ser una forma adecuada de adaptar las asignaturas de idiomas a las demandas del EEES. El blended learning y las WebQuests suscitan el pensamiento de orden superior, fomentan el desarrollo de las competencias instrumentales, sistémicas e interpersonales y pueden ser fácilmente integradas en un sistema de transferencia y acumulativo basado en los créditos ECTS.

Palabras clave: Espacio Europeo de Educación Superior (EEES), formación combina$\mathrm{da} /$ blended learning, WebQuests, Inglés para Fines Específicos.

1. An earlier, shorter version of this paper was presented at the 6th International AELFE Conference, Lisbon, September 13-15, 2007. 


\section{INTRODUCTION: BLENDED LEARNING AND THE NEW EUROPEAN HIGHER EDUCATION AREA (EHEA)}

The term blended learning refers to those language courses that combine an appropriate use of technology with face-to-face classroom activities (Sharma and Barrett, 2007: 7). This use of technology usually involves online activities, which allow the easy integration of inperson classroom training with distant learning. Although there are many teaching situations in which a blended learning environment may be useful, in this paper I want to focus on the way it may help teachers meet the new methodological demands and structural changes that the new European Space for Higher Education is bringing about in the university system. The use of a student-oriented methodology, ECTS credits and transversal competences can be easily fostered through the integration of WebQuests within face-to-face classroom activities, an interesting form of blended learning.

In 2010 there will be a new European Space for Higher Education, which is bringing about important structural changes in the university system in more than 40 countries. These countries are committed to creating a common space for higher education that will improve the quality and competitiveness of European universities and will foster student mobility throughout Europe. The process began in 1999 in Bologna, Italy when an official declaration was signed by 29 countries to reform the structures of their higher education systems in a convergent way. A series of important objectives were set in the first Bologna declaration (1999)2:

- The adoption of a common framework of readable and comparable degrees and the development of comparable criteria and methods for quality assurance.

- The introduction of ECTS-compatible credit systems.

- The implementation of a three-cycle system. A bachelor's degree of 180"240 ECTS credits, a master's degree of 90-120 ECTS credits and a doctoral degree.

- The promotion of student and teacher mobility.

These objectives have been developed through subsequent governmental meetings in Prague (2001), Berlin (2003), Bergen (2005) and London (2007) and have been accompanied by a set of new pedagogical approaches suggested to meet the new demands. An interesting way to follow the progressive implementation of the higher education area is provided by the Trends Project, which has been designed to gather reliable information about the process. At present five Trends reports have been released prepared for the bi-annual Bologna meetings of Education Ministers, see Trend I (1999), Trends II (2001), Trends III (2003), Trends IV (2005), Trends $\mathrm{V}(2007)^{3}$.

2. http://ec.europa.eu/education/policies/educ/bologna/bologna.pdf

3. http://www.eua.be/fileadmin/user_upload/files/EUA1_documents/OFFDOC_BP_trend_I.1068715136182.pdf, http://www.eua.be/fileadmin/user_upload/files/Publications/Final_Trends_Report_May_10.pdf, http://www.eua.be/fileadmin/user_upload/files/EUA1_documents/Trends2003final.1065011164859.pdf, http://www.eua.be/fileadmin/user_upload/files/EUA1_documents/TrendsIV_FINAL.1117012084971.pdf, http://www.eua.be/fileadmin/user_upload/files/EUA1_documents/OFFDOC_BP_trend_II.1068715483262.pdf. 


\section{The NEW METhodologies IN THE EHEA}

The Bologna Process has generated a large number of reports, documents and declarations that may overwhelm teachers when they face the challenge of adapting their subjects to the new system. Changes are expected regarding the general organisation of bachelors, masters and doctorates but also regarding the very subjects that make up the degrees. The Tuning Educational Structures in Europe project has aimed at providing the reference points that teachers seek to adapt their subjects. The project focuses on higher education institutions and subject areas and is developing "a methodology to (re-) design, develop, implement and evaluate study programmes for each of the Bologna cycles" (Julia González and Robert Wagenaar, 2008: 9). In this sense, there are three important pillars that have to be taken into account when transforming subjects, namely, the new role of teachers and students, the need to introduce ECTS credits and the importance that the development of competences acquires.

The EHEA is fostering a student-oriented approach to teaching so that the study programme contents are determined by the knowledge and skills that students need. Thus, the programmes are output-oriented, rather than input-oriented. In student-centred learning teachers become guides or facilitators of learning and provide students with multiple ways of accessing and processing information ${ }^{4}$. On the other hand, students take a more active role and become responsible for their learning. Higher order thinking activities like problem-solving are specially fostered rather than memorising isolated facts. In the same line, goals and objectives are based on authentic problems and the students' needs. The learning becomes autonomous and selfpaced rather than prescribed by the teacher (Atsusi Hirumi, 2002).

To implement this student-oriented approach, there has also been an important change in the credit structure. The European Credit Transfer and Accumulation System (ECTS) is based on the student workload required to achieve the objectives of a programme rather than on the number of hours of face-to-face instruction provided by the teacher. One credit stands for around 25 to 30 working hours and the workload of a full-time student during one academic year is 60 credits. The workload is not reduced to attending lectures and seminars, it also contains independent and private study, preparation of projects and examinations. Thus, the objectives of the programme are specified in terms of the learning outcomes to be acquired in a specific number of working hours or ECTS credits. These learning outcomes are defined as: "sets of competences, expressing what the student will know, understand or be able to do after completion of a process of learning, long or short" (Julia González and Robert Wagenaar, 2008: 83). This student-centred teaching approach, together with the introductions of ECTS to measure student workload is leading teachers to design their subjects with a series of pedagogical aims in mind such as the stimulation of active independent learning, reflection and self-reflection of the learning process and the use of collaborative learning.

The third important change that needs to be considered is the importance that competences acquire since they become the object of the educational programme. They represent "a dynamic combination of knowledge, understanding, skills and abilities" (Julia González and Robert Wagenaar, 2008: 17). There are two main types of competences, subject-specific and generic

4. For a detailed analysis of the new role of language teachers in the context of European convergence see Martínez Lirola (2007). 
ones. The former have traditionally been considered the core of university degree programmes, whereas the latter are the ones specially fostered by the Bologna process. According to the Tuning project there are three types of generic competences:

- Instrumental competences: cognitive abilities, methodological abilities, technological abilities and linguistic abilities;

- Interpersonal competences: individual abilities like social skills (social interaction and co-operation);

- Systemic competences: abilities and skills concerning whole systems (combination of understanding, sensibility and knowledge; prior acquisition of instrumental and interpersonal competences required) (Julia González and Robert Wagenaar, 2008: 17).

Generic competences are very important for the future employability of students and for their ability to sustain lifelong learning. Out of instrumental, interpersonal and systemic competences more than thirty possible generic competences emerge, thus, it is impossible to introduce all of them in a single subject. The Tuning project has held consultation with graduates, employers and academics on the importance of thirty generic competences and has evaluated how well higher education institutions develop them. Regarding instrumental competences the four most important ones were: the capacity for analysis and synthesis, problem solving, information management skills and the capacity for organisation and planning. Regarding the systemic competences the most significant ones were: capacity to learn, capacity for applying knowledge in practice, capacity to adapt to new situations, concern for quality and ability to work autonomously. Finally, the only interpersonal competence that appeared in this "top 10" of competences was teamwork (Julia González and Robert Wagenaar, 2008: 42, 52).

\section{The USE OF Webquests IN THE EHEA}

In the EHEA the new teaching methodology should be student-oriented, should make use of ECTS credits and should foster transversal competences. A good means to integrate all these aspects is to use WebQuests or LanguageQuests as an effective means to meet these requirements in Second Language Acquisition (SLA) and more specifically in the area of ESP. WebQuests are inquiry-oriented activities in which some or all of the information that learners interact with comes from resources on the internet (Dodge, 1995). Thus, they were originally designed to integrate complex aspects of a discipline with new technologies. These tasks try to elicit higher order thinking, so they are not used just to look for information-like treasure hunts-but to treat information in a creative or critical way since students engage in analysis, synthesis, judgement and problem solving activities (Dodge, 2001). March has widened this definition and has worked on delimiting what a WebQuest really is:

A WebQuest is a scaffolded learning structure that uses links to essential resources on the World Wide Web and an authentic task to motivate students' investigation of a central, open-ended question, development of individual expertise and participation in a final group process that attempts to transform newly acquired information into 
a more sophisticated understanding. The best WebQuests do this in a way that inspires students to see richer thematic relationships, facilitate a contribution to the real world of learning and reflect on their own metacognitive processes (March, 2003: 43).

LanguageQuests are the SLA adaptation of WebQuests and are based on a constructivist approach (Williams and Burden, 1997) and project-based learning (Grant, 2002). These are WebQuests aimed at foreign language learning that combine a specific task that students have to carry out with an interest in the language they will have to use to complete it. ${ }^{5}$ Koenraad and Westhoff have underlined that in LanguageQuests there is a focus not just on meaning but also on form and on the correct use of the second language. It should be used for communication and creation of information. To meet these demands specific scaffolding activities and tools for language learning should be developed by the teacher to facilitate the learning process (Koenraad and Westhoff, 2003: 9). Therefore, WebQuests are clearly student-centred since it is the student that has to draw the necessary connections but students should be guided by the teacher who provides the necessary scaffolding. The scaffolding is a framework provided to encourage students to go beyond their initial capacities. According to Dodge, it is used so that the bar of what students can produce may be raised (2001: 8) and it is at the heart of the WebQuest model (March, 2003: 43). Scaffolding may be provided through glossaries, listening guides, note taking frameworks, reference material (e.g. online dictionaries) and charts among other possibilities.

WebQuests are a very effective way to promote instrumental, systemic and interpersonal competences and they are especially useful in the teaching of an ESP course for engineering. They can be used to create professional environments and develop skills associated with the engineering discipline at the same time as students become more motivated since they are using new technologies and authentic texts (Luzón Marco, 2002: 23). Besides, as PérezLlantada underlines, ESP subjects can be a perfect means to develop and practice these competences since the topics used in Technical English come from the other subjects in the degree. The learning of ESP fosters the use, transference and interconnection of the concepts learned in all the degree subjects (2007: 14). Thus, it is a subject that especially allows the introduction of transversal issues and competences.

Regarding instrumental competences the capacity for analysis and synthesis may be developed through the reading of different webpages - especially if they offer contrastive or contradictory points-of-view. Students will need to extract their basic arguments in order to compare them and contribute with their knowledge to the discussion. In this type of exercises information management skills and the capacity for organisation and planning are also equally important since students have to learn to organise the new information they acquire and do something with it. A good way to practice these instrumental competences is through problem solving activities launched by the WebQuest. In the teaching of an ESP course for engineering WebQuests can be specially used to create professional environments and develop skills associated

5. Pérez Torres has written a very interesting monograph on the design of WebQuests for SLA with a special emphasis on vocabulary acquisition and reading practice. In her study the advantages of WebQuests for SLA learning are specially considered (Pérez Torres, 2006). See also the Dutch project on TalenQuests (Talen means languages in Dutch) at http://www.talenquest.nl 
with the engineering discipline at the same time as students become more motivated since they are using new technologies and authentic texts (Luzón Marco, 2002: 23). Orna Montesinos (2006) has proposed a very interesting WebQuest for engineering students in which they have to enter a competition to select the best skyscrapers of the 20th century, which could be very useful to develop instrumental competences.

Regarding systemic competences, the capacity to learn can obviously be developed through the Internet, as long as a guide is provided and the tasks are controlled by the teacher. In the preliminary or background stage (March, 2003) of a WebQuest students gain common general knowledge on a subject before specialising in one perspective. The capacity for applying knowledge in practice and the capacity to adapt to new situations should also be part of a good WebQuest. Once information is gathered and processed students have to make something new out of what they have learned. According to March (2003) one possible way to do so is by applying lessons from global problems to local issues. By contextualising the topic and bringing it closer to the students' daily life, they become more motivated at the same time as they practice generic competences.

Finally, the Tuning project revealed that, regarding interpersonal competences, teamwork was the only one considered by graduates and employers within the "top 10" of competences (Julia González and Robert Wagenaar, 2008: 42, 52). WebQuests are devised to be carried out in teams. Each member of the team usually plays a role or is assigned a specific task. The final goal of the WebQuest can only be attained by gathering the work of all the team members and by making something together. Thus, social interaction and cooperation are basic competences they will have to display to reach the final goal. Besides, they will need to communicate not just with the members of the team but also with other teams and with experts in the field through forums and specialised blogs. In sum, WebQuests are student-oriented and provide the perfect environment for the development of instrumental, systemic and interpersonal skills. Besides, they can be easily adapted to an accumulation and transfer system based on ECTS credits since they are an ideal means to combine face-to-face learning with autonomous and collaborative work in very productive ways.

\section{Webquests ANd blended learning: a PRACTICAL EXAMPle}

In an ESP course for Engineering we could introduce a WebQuest to explore the safety issues that might have failed in the 9/11 Word Trade Centre collapse or that could have been improved (see Figure 1). It is important to look for an up-to-date topic that catches the students' attention and interest. This WebQuest could be placed at the end of a unit where they would have studied modal verbs of obligation and necessity, modal passives and the use of the imperative, together with vocabulary about safety measures. When WebQuests are clearly integrated within the students' programme they become a more authentic and motivating way to practice the grammar and the vocabulary learned in

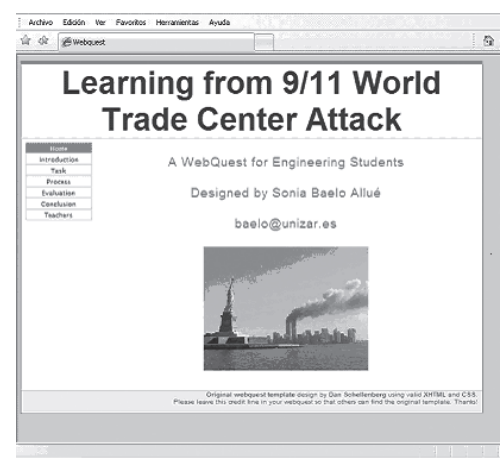

Figure 1. 
each unit. An additional way to make students more interested in the task and more aware of their learning process is to encourage each team to create a blog ${ }^{6}$ where they can write an account of each step taken and a summary of what they are learning. It is a way of creating an e-portfolio of the students' work, which should develop the students' self-reflection on their learning process. The teacher can follow each team's steps through their blogs and introduce comments in case some further guidance is needed. It is a means of introducing formative assessment since the blog allows students to evaluate their progress and improve on their previous performance. Besides, the blog can also be useful for summative assessment since the teacher can assess the activity and the completion of the learning outcomes of the WebQuest.

For blended learning to be effective and meet the EHEA requirements, the WebQuest should be fully integrated within the face-to-face sessions. As Sharman and Barrett put it "if there is a close correlation between the content of the lesson and the online materials, the online material will be used more enthusiastically" (2007: 14). Thus, the WebQuest could be preceded by an initial face-to-face introductory session to give students a common feedback about the subject. In this session students could watch one of NOVA science series on DVD on the 9/11 attacks such as Why The Towers Fell (2002) or Building on Ground Zero (2006) which would be very suitable to obtain background information on the subject. The teacher would provide the necessary scaffolding by means of an outline of the documentary and a review of the basic vocabulary used. In this session students could be organised into teams and individual tasks could be assigned to complete the WebQuest. The time students spend completing their individual and team tasks will not be part of the contact hours of face-to-face teaching but will be part of the workload required to achieve the objectives of the programme. This blended learning approach is especially adequate in the EHEA since ECTS credits measure not just face-to-face sessions but the students' total workload.

In the introduction of the WebQuest proposed (see Figure 2) a professional environment is simulated. Interdisciplinary learning is fostered since the use of the Internet allows students to access authentic material and to activate their knowledge of concepts that they may have learned in other degree subjects. Besides, the use of the Internet provides endless exposure to the target language, makes students more autonomous and helps them become independent learners, which are objectives of the EHEA. In the task section (see Figure 3) there is a detailed explanation of what students will be expected to do to complete their task. In this WebQuest they have to prepare an oral presentation about the safety measures of a skyscraper to be designed for their home city, in this case Zaragoza. Students take an international, very significant event like the WTC collapse and bring it to a local situation. As March (2003) suggests, when topics are brought closer to the students' daily life, they become more motivated. Besides, the fact that they are organised in teams helps

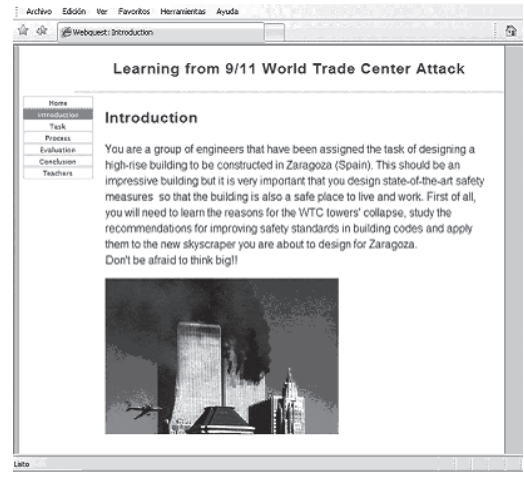

Figure 2.

6. For an interest review of the possibilities that weblogs may offer for language teaching and learning see Kavaliauskiené, 2007. 


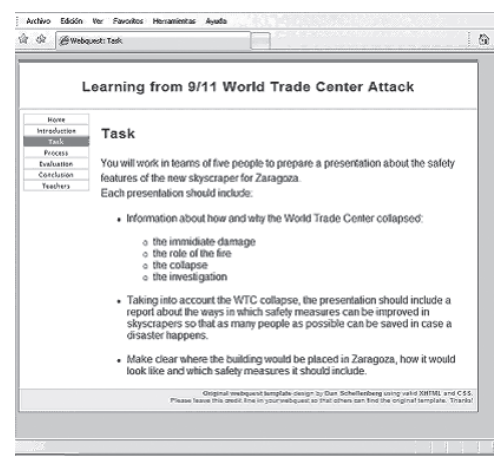

Figure 3.

them develop interpersonal competences such as social interaction and cooperation.

The process section (see figure 4) is the most important part of any WebQuest. It is here that learners are guided through a set of activities that involve a certain degree of research and higher-order thinking. Thus, teachers become guides or facilitators since they have to guide students through all the resources that the Internet offers to practice language learning. Since the internet provides excellent resources for students to practice receptive skills of listening and reading, these are the areas that students will especially practice. The first step they have to take

is to read an official document, FEMA (Federal Emergency Management Agency) Executive Summary, a study of the performance of buildings at the WTC site. They have to fill in a chart with specific information taken from the text. Through this exercise students develop instrumental competences since they can practice their capacity for analysis and synthesis. Besides, through on-screen reading students can access meaning on demand by clicking on the online dictionary hyperlinks provided. This scaffolding will help them learn new words and review those they had learned in the face-to-face sessions.

The second step they have to take (see figure 5) gives them a chance to practice listening skills. Online

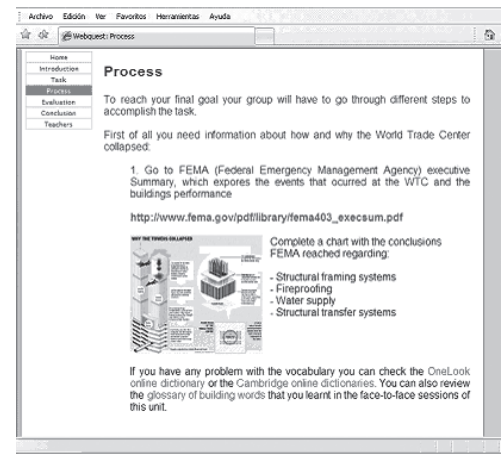

Figure 4. listening allows students to pause at will and repeat the listening as many times as they need. In this case the fragments are very short, no more than two minutes long, and deal with specific issues from the impact to the final collapse. Each member of the team focuses on one specific video and will have to interchange the new information with the other members of the team. The capacity to learn, a key systemic competence is thus developed. The third step (see figure 6) is a reading exercise of the National Institute of Technology and Standards' suggestions

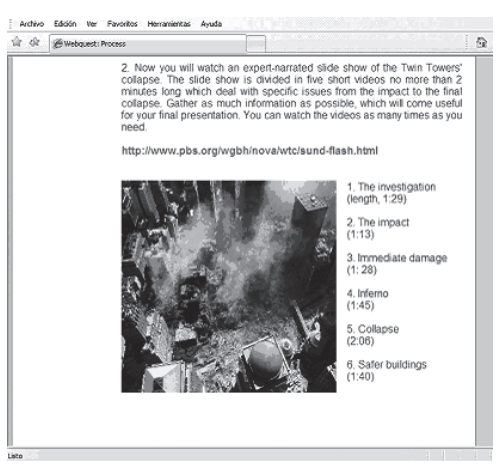

Figure 5 .

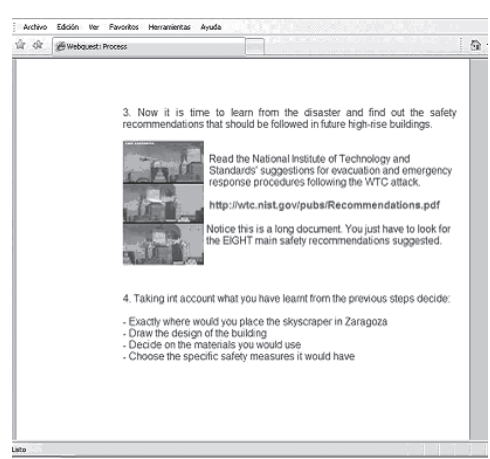

Figure 6. 
for evacuation and emergency response procedures following the WTC attack. Unlike the reading in step 1, this is a long text (29 pages long). Students have to get used to working with long documents since this is something they will have to do in their professional careers. The document length makes it ideal for students to develop skimming and scanning techniques. Skimming the text will help them cover large amounts of material in a limited period of time, whereas scanning will help them find answers to specific questions. In this case they have to look for the eight main recommendations that can be extracted from the report.

The forth step (also figure 6) makes students develop systemic competences. They have to apply the knowledge they have gathered in the previous steps into practice. They also have to adapt to a new situation as they apply lessons from global problems-what they have learned about safety standards - to local issues such as the building of a skyscraper in Zaragoza. In the fifth and last step (see figures 7 and 8) they have to make use of basic instrumental competences like information management skills and the capacity for organisation and planning. This is the moment when, after practicing receptive skills like listening and reading, students have to practice productive skills of speaking and writing. The team has to prepare a presentation on what they have learned from the collapse and design a new safe building for Zaragoza. This presentation will be given in a face-to-face session because productive skills usually need a teacher who evaluates and gives language feedback. Thus, WebQuests can combine autonomous learning with traditional seminars and the workload of the students can be easily measured through ECTS credits.

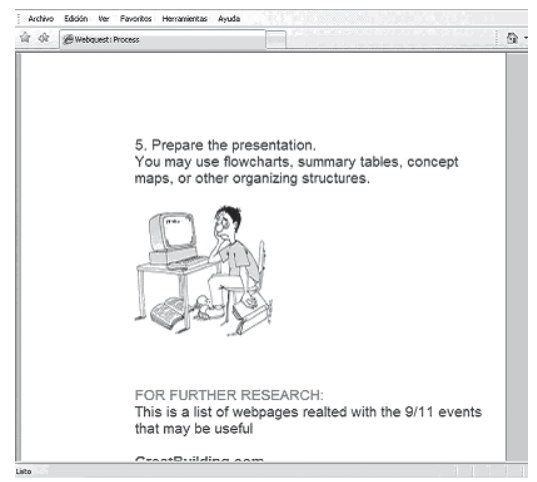

Figure 7.

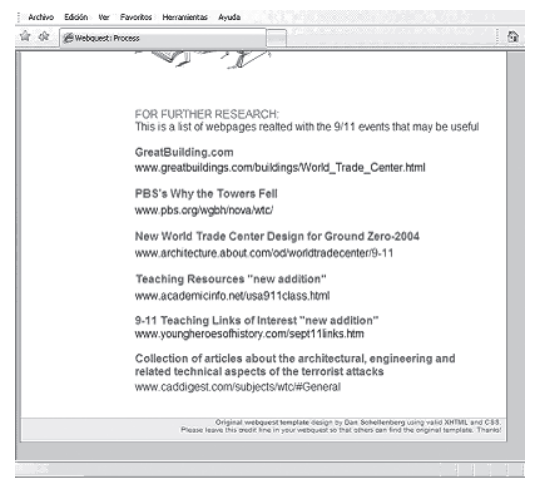

Figure 8 .

\section{Conclusion}

The European Space of Higher Education is bringing about structural changes and new pedagogical approaches to increase quality and competitiveness. In this paper we have proposed blended learning as a means to meet these demands, combining the use of WebQuests and face-to-face sessions to foster a student-oriented teaching approach, the development of instrumental, systemic and interpersonal skills. Moreover, blended learning can be easily adapted to the ECTS credit system. The use of WebQuests in ESP courses is specially useful since students can benefit from a teaching approach that combines the use of authentic material of 
their field, an aim-oriented language, the immersion in a real professional environment and the collaborative and autonomous learning that these tasks foster. The design of WebQuests is based on five building blocks (Dodge, 1998) — introduction, task, process, resources, evaluation and conclusion. In this paper we have not dealt with the evaluation process of these tasks and this is an area that needs further study in connection with the EHEA. Instead, we have tried to illustrate in which ways WebQuests could be developed to meet the demands of an ESP course and the new teaching approaches of the Bologna declaration. The Internet is full of resources for teaching and learning languages and blended learning can be an ideal means of developing writing, listening, oral and reading skills at the same time as higher order thinking is activated and generic competences are developed.

\section{REFERENCES}

Dodge, B. (1995). "Some Thoughts about WebQuests". Available from: http://webquest.sdsu.edu/ about_webquests.html, accessed 09 November, 2007.

Dodge, B. (1998). "Building Blocks of a WebQuest". Available from: http://projects.edtech.sandi.net/ staffdev/buildingblocks/p-index.htm, accessed 09 November, 2007.

Dodge, B. (2001). "FOCUS: Five Rules for Writing Great WebQuests", in Learning \& Leading with Technology, 28, 8: 6-9.

González, J. and Wagenaar, R. (eds.) (2008). Universities' Contribution to the Bologna Process: An Introduction. Bilbao: Publicaciones de la Universidad de Deusto.

Grant, M. (2002). "Getting a Grip on Project-based Learning: Theory, Cases, and Recommendations", in Meridian: A Middle School Computer Technologies Journal, 5, 1. Available from: http:/ /www.ncsu.edu/meridian/win2002/514/index.html, accessed 09 November, 2007.

Hirumi, A. (2002). "Student-centered, Technology-rich, Learning Environments (SCenTRLE): Operationalizing Constructivist Approaches to Teaching and Learning", in Journal for Technology and Teacher Education, 10, 4: 497-537.

Kavaliauskiene, G. (2007). "Weblogs in Language Teaching and Learning", in Teaching English with Technology: A Journal for Teachers of English, 7, 1. Available from: http:// www.iatefl.org.pl/call/j_lesson27.htm, accessed 09 November, 2007.

Koenraad, A.L.M. and Westhoff, G. J., (2003) "Can you Tell a LanguageQuest When you See One? Design Criteria for TalenQuests". Paper presented at the Eurocall Conference 2003. Available from: http://www.feo.hvu.nl/koen2/Home/talenquest/TQEurocall.pdf, accessed 09 November, 2007.

Luzón Marco, M.J. (2002). "Internet Content-based Activities for English for Specific Purposes", in English Teaching Forum, 40. Available from: http:/exchanges.state.gov/forum/vols/vol40/ no3/p20.pdf, accessed 09 November, 2007.

March, T. (2003). "The Learning Power of WebQuests", in Educational Leadership, 61, 4: 42-47.

Martínez Lirola, M. (2007). "El nuevo papel del profesor universitario de lenguas extranjeras en el proceso de convergencia europea y su relación con la interacción, la tutoría y el aprendizaje autónomo". Porta Linguarum: An International and Interuniversity Journal of Foreign Language Didactics, 7: 31-43, available from: http://www.ugr.es/ portalin/articulos/ PL_numero7/3\%20Maria\%20Martinez.pdf, accessed 11 November, 2008.

Orna Montesinos, C. (2006). "Designing WebQuests for an English for Construction Course", en C. Neumann, R. Plo Alastrué y C. Pérez-Llantada Auría (eds.), Proceedings of the 5th 
International AELFE Conference. Zaragoza: Prensas Universitarias de Zaragoza. Available from: http://www.unizar.es/aelfe2006/ALEFE06/5.newtechnologies/90.pdf, accessed 09 November, 2007.

Pérez-Llantada Auría, M.C. (2007). "Formación en competencias instrumentales, interpersonales y sistémicas para el aprendizaje de lenguas extranjeras en el marco del EEES". Available from: http://www.unizar.es/eees/innovacion06/COMUNIC_PUBLI/BLOQUE_II/ CAP_II_10.pdf, accessed 09 November, 2007.

Pérez Torres, I. (2006). Diseño de WebQuests para la Enseñanza/Aprendizaje del Inglés como Lengua Extranjera: Aplicaciones en la Adquisición de Vocabulario y la Destreza Lectora. Granada: Editorial Universidad de Granada.

Sharma, P. and B. Barrett (2007). Blended Learning: Using Technology in and beyond the Language Classroom. Oxford: Macmillan.

Williams, M. and Burden, R. (1997). Psychology for Language Learners: A Social Constructivist Approach. Cambridge: Cambridge University Press.

http://ec.europa.eu/education/policies/educ/bologna/bologna.pdf, accessed 09 November, 2007.

ht tp://www.eua.be/fileadmin/user_upload/files/EUA1_documents/ OFFDOC_BP_trend_I.1068715136182.pdf, accessed 09 November, 2007.

ht t p :// www.eua.be/fileadmin/user_upload/files/EUA1_documents/ OFFDOC_BP_trend_II.1068715483262.pdf, accessed 09 November, 2007.

http://www.eua.be/fileadmin/user_upload/files/EUA1_documents/Trends2003final.1065011164859.pdf, accessed 09 November, 2007.

http://www.eua.be/fileadmin/user_upload/files/EUA1_documents/ TrendsIV_FINAL.1117012084971.pdf, accessed 09 November, 2007.

http://www.eua.be/fileadmin/user_upload/files/Publications/Final_Trends_Report_May_10.pdf, accessed 09 November, 2007. 